\title{
Transport of $\mathrm{o}$-Serine via the Amino Acid Transporter ATB ${ }^{0,+}$ Expressed in the Colon
}

\author{
Takahiro Hatanaka*, Wei Huang ${ }^{\star}$, Takeo Nakanishi, Christy C. Bridges ${ }^{\star}$, Sylvia B. Smith ${ }^{\dagger}$, \\ Puttur D. Prasad ${ }^{\ddagger}$, Malliga E. Ganapathy ${ }^{\S}$, and Vadivel Ganapathy ${ }^{\star}, \neq, 1$ \\ *Department of Biochemistry and Molecular Biology, Medical College of Georgia, Augusta, \\ Georgia 30912 \\ †Department of Cellular Biology and Anatomy, Medical College of Georgia, Augusta, Georgia \\ 30912 \\ ‡Department of Obstetrics and Gynecology, Medical College of Georgia, Augusta, Georgia 30912 \\ §Department of Medicine, Medical College of Georgia, Augusta, Georgia 30912
}

\begin{abstract}
D-Serine, synthesized endogenously in the brain, is an important modulator of glutamatergic neurotransmission. Since colonic bacteria produce ${ }_{\mathrm{D}}$-serine, we asked the question whether there are transport mechanisms in the colon that might make this exogenously produced $\mathrm{D}$-serine available to the host. Here we identify for the first time an amino acid transporter in the intestine for high-affinity active transport of ${ }_{\mathrm{D}}$-serine. This transporter, called $\mathrm{ATB}^{0,+}$, is a $\mathrm{Na}^{+}-$and $\mathrm{Cl}^{-}-$ coupled transporter for L-enantiomers of neutral and cationic amino acids. Here we demonstrate that $\mathrm{ATB}^{0,+}$ is also capable of mediating the $\mathrm{Na}^{+}$- and $\mathrm{Cl}^{-}$-coupled transport of ${ }_{\mathrm{D}}$-serine. The affinity of $\mathrm{ATB}^{0,+}$ for ${ }_{\mathrm{L}-s e r i n e}$ and $\mathrm{D}_{\mathrm{D}}$-serine is similar, the $K_{t}$ value for the two enantiomers being $\sim 150 \mu \mathrm{M}$. In addition to $\mathrm{D}-$ serine, $\mathrm{ATB}^{0,+}$ transports $\mathrm{D}-$ alanine, $\mathrm{D}-$ methionine, $\mathrm{D}-$ leucine, and $\mathrm{D}-$ tryptophan. However, several other neutral and cationic amino acids that are transportable substrates for $\mathrm{ATB}^{0,+}$ as L-enantiomers are not transported when presented as D-enantiomers. $\mathrm{ATB}^{0,+}$ is expressed in the intestinal tract, interestingly not in the proximal intestine but in the distal intestine. Expression is most predominant in the colon where the transporter is localized to the luminal membrane of colonocytes, making this transporter uniquely suitable for absorption of bacteria-derived $\mathrm{D}$-serine.
\end{abstract}

\begin{abstract}
D-Amino acids are generally considered foreign to metabolic pathways in mammals. Almost all mammalian enzymes are selective for L-amino acids with the notable exception of Damino acid oxidase. D-amino acids are found in the plasma, but they are believed to originate from the diet or from the intestinal microbial flora (1-3). Since D-amino acids do not participate in metabolic pathways in mammals, the biological significance of these amino acids has been questioned. There is evidence however for beneficial effects of certain D-amino acids $(2,3)$. There is also evidence of a physiological function for $\mathrm{D}$-serine in the modulation of glutamatergic neurotransmission by activation of glutamate signaling via the
\end{abstract}

\footnotetext{
${ }^{1}$ To whom correspondence and reprint requests should be addressed at Department of Biochemistry and Molecular Biology, Medical College of Georgia, Augusta, GA 30912. Fax: 706-721-6608., vganapat@ mail.mcg.edu..
} 
$N$-methyl-D-aspartate (NMDA) receptor $(4,5)$. Interestingly, this D-amino acid is generated endogenously in the brain by racemization of $\mathrm{L}_{\mathrm{L}}$-serine mediated by serine racemase $(6,7)$.

D-amino acids are abundant in bacteria (2) and therefore are expected to be present in significant quantities in the colon and ileum where bacterial colonization is prevalent. Since some of the D-amino acids are now known to possess important physiological and pharmacological functions, the issue of intestinal absorption of bacteria-derived and dietary D-amino acids becomes important. If there are effective mechanisms in the intestinal tract for the entry of luminal D-amino acids into blood, it is possible for exogenous D-amino acids to exert biological effects. Several transporters that mediate the intestinal absorption of amino acids have been cloned recently (8). To date, only two amino acid transporters have been shown to transport D-amino acids to any significant extent $(9,10)$. They are system L1 and system asc 1 . Both are facilitative transporters that mediate amino acid exchange across the plasma membrane. They are not active because their transport function is not coupled to any driving force. System L1 and system asc1 are expressed in the intestine. Interestingly, these transporters are heterodimeric, both containing the heavy chain of the $4 \mathrm{~F} 2$ cell surface antigen (4F2hc) as a common subunit. Since 4F2hc is localized exclusively to the basolateral membrane of the absorptive cells of the kidney and intestine (11), system L1 and system asc1 are likely to participate in the efflux of amino acids from the intestinal mucosal cells into the blood. It is not known at present if there are transport systems in the brush border membrane of the intestinal epithelial cells that might mediate the entry of D-amino acids from the lumen into the cells.

The present study was undertaken to compare various amino acid transporters that are expressed in the intestine for their ability to transport ${ }_{\mathrm{D}}$-serine. Here we report for the first time the identification of an amino acid transporter in the intestine for high-affinity active transport of ${ }_{D}$-serine.

\section{METHODS}

\section{Functional expression of amino acid transporter cDNAs in mammalian cells}

The functional expression of the transporter cDNAs was carried out in human retinal pigment epithelial (HRPE) cells using the vaccinia virus expression system $(12,13)$. The transporter clones used in these studies were originally isolated from different cDNA libraries. All of these clones have been shown to be functional in heterologous expression systems (8). Transport measurements were made at $37^{\circ} \mathrm{C}$ for 15 min with $\left[\mathrm{D}^{-}{ }^{3} \mathrm{H}\right]$ serine or $\left[{ }^{3} \mathrm{H}\right]$ glycine. The transport buffer was $25 \mathrm{mM}$ Hepes/Tris (pH 7.5) containing $140 \mathrm{mM}$ $\mathrm{NaCl}, 5.4 \mathrm{mM} \mathrm{KCl}, 1.8 \mathrm{mM} \mathrm{CaCl}_{2}, 0.8 \mathrm{mM} \mathrm{MgSO}_{4}$, and $5 \mathrm{mM}$ glucose. Endogenous transport activity was always determined in parallel using cells transfected with vector alone. The cDNA-specific transport activity was calculated by adjusting for the endogenous activity.

\section{Functional expression of mouse $\mathrm{ATB}^{0,+}$ CDNA in Xenopus laevis oocytes}

For the functional expression of $\mathrm{ATB}^{0,+}$ in oocytes, mature oocytes from Xenopus laevis were isolated by collagenase treatment $(12,13)$. Oocytes were manually defolliculated and 
then used for injection with mouse $\mathrm{ATB}^{0,+} \mathrm{cRNA}$ or water. cRNA was synthesized using the mMesSAGE mMACHINE kit (Ambion, Austin, TX). The transport of D-amino acids via mouse $\mathrm{ATB}^{0,+}$ in oocytes was monitored electrophysiologically using the twomicroelectrode voltage-clamp technique $(12,13)$. The membrane potential was held steady at $-50 \mathrm{mV}$. Oocytes were perfused with different L- and D-enantiomers of amino acids and the induced current was monitored. The induced current was taken as the measure of transport rate. The composition of the perfusion buffer was $10 \mathrm{mM}$ Hepes/Tris (pH 7.5), containing $100 \mathrm{mM} \mathrm{NaCl}, 2 \mathrm{mM} \mathrm{KCl}, 1 \mathrm{mM} \mathrm{MgCl}_{2}$, and $1 \mathrm{mM} \mathrm{CaCl}_{2}$.

\section{Immunofluorescent localization of $\mathrm{ATB}^{0,+}$ protein in mouse colon}

For immunofluorescent localization of $\mathrm{ATB}^{0,+}$ in mouse colon, a polyclonal antibody was raised against the peptide TDHEIPTISGSTKPE corresponding to the C-terminal region 624-637. The specificity of the antibody was tested in Western blot using HRPE cells transfected with either vector alone or mouse $\mathrm{ATB}^{0,+} \mathrm{cDNA}$. The antibody recognized a single protein $(64 \mathrm{kDa})$ in cDNA-transfected cells. There was no immunoreactive protein in vector-transfected cells. This antibody was used to localize $\mathrm{ATB}^{0,+}$ in mouse colon by immunofluorescent confocal microscopy as described previously $(14,15)$.

\section{RESULTS AND DISCUSSION}

We evaluated the function of 10 different amino acid transporter clones with respect to transport of ${ }_{D}$-serine in HRPE cells (Fig. 1). All of these transporters are expressed in the intestinal tract as evidenced from Northern blot. The transporters tested include three energy-independent, heterodimeric facilitative transporters $\left(\mathrm{L} 1, \mathrm{~L} 2\right.$, and $\left.\mathrm{b}^{0,+}\right)$, three subtypes of the $\mathrm{Na}^{+}$-coupled system A (ATA1, ATA2, and ATA3), two subtypes of the $\mathrm{Na}^{+}-$and $\mathrm{H}^{+}-$ coupled system $\mathrm{N}$ (SN1 and SN2), the $\mathrm{Na}^{+}$-coupled system $\mathrm{ATB}^{0}$, and the $\mathrm{Na}^{+}$- and $\mathrm{Cl}^{-}$coupled system $\mathrm{ATB}^{0,+}$. Among the facilitative transporters, system L1 (LAT1/4F2hc) and $\mathrm{b}^{0,+}\left(\mathrm{b}^{0,+} \mathrm{AT} / 4 \mathrm{~F} 2 \mathrm{hc}\right)$ showed significant ability to transport $\mathrm{p}$-serine. The L2 (LAT2/4F2hc)

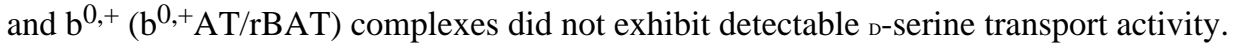
Among the subtypes of system A, ATA1 and ATA2 showed $\mathrm{D}$-serine transport activity, but ATA3 did not. SN1 and SN2 did not transport $\mathrm{p}$-serine. $\mathrm{ATB}^{0}$ was able to transport $\mathrm{D}$-serine to a marked extent, its transport activity being much higher than that of systems L1, $\mathrm{b}^{0,+}$, ATA1, and ATA2. The ability to transport ${ }_{\mathrm{D}}$-serine was the highest, however, for the $\mathrm{Na}^{+}-$ and $\mathrm{Cl}^{-}$-coupled transporter $\mathrm{ATB}^{0,+}$. $\mathrm{ATB}^{0,+}$ belongs to the gene family of neurotransmitter transporters whose transport function is energized by the $\mathrm{Na}^{+}$gradient, $\mathrm{Cl}^{-}$gradient, and membrane potential $(12,13,16)$. The functional activities of $\mathrm{ATB}^{0}$ and $\mathrm{ATB}^{0,+}$ have been demonstrated in the brush border membrane of the intestinal epithelial cells $(17,18)$, and therefore it is likely that these two transporters mediate the active absorption of $\mathrm{D}$-serine from the lumen into the mucosal cells. Based on the energetics of these two transport systems, $\mathrm{ATB}^{0,+}$ is expected to play the leading role in this process.

The characteristics of $\mathrm{D}_{\mathrm{D}}$ serine transport via $\mathrm{ATB}^{0,+}$ were studied in detail (Fig. 2). The transport process was saturable with a Michaelis-Menten constant of $180 \pm 16 \mu \mathrm{M}$. It is a $\mathrm{Na}^{+}$- and $\mathrm{Cl}^{-}$-coupled process with a $\mathrm{Na}^{+}: \mathrm{Cl}^{-}$:D-serine stoichiometry of $2: 1: 1$. ATB ${ }^{0,+}$ is known to transport several L-amino acids $(12,13,16)$. To compare the relative affinity of 
the transporter for ${ }_{\mathrm{L}}$-serine and $\mathrm{D}$-serine, we assessed the ability of these two enantiomers to compete with glycine for transport via $\mathrm{ATB}^{0,+}$. Surprisingly, there was no difference between the inhibitory potencies of these two enantiomers $\left(\mathrm{IC}_{50}\right.$ values for $\mathrm{L}_{\mathrm{L}}$-serine and $\mathrm{D}$ serine were $168 \pm 8$ and $150 \pm 11 \mu \mathrm{M}$, respectively). Thus, $\mathrm{ATB}^{0,+}$ does not differentiate between ${ }_{\mathrm{L}}$-serine and $\mathrm{D}$-serine for interaction and transport.

To determine whether $\mathrm{ATB}^{0,+}$ is capable of transporting other D-amino acids, two different approaches were used (Table 1). In the first approach, the transport function of $\mathrm{ATB}^{0,+}$ was measured in HRPE cells using glycine as the substrate for the transporter. To compare the interaction of $\mathrm{ATB}^{0,+}$ with L- and D-enantiomers of various amino acids, the ability of these amino acids to inhibit $\mathrm{ATB}^{0,+}$-mediated glycine transport was assessed. All neutral and cationic amino acids tested were potent inhibitors of $\mathrm{ATB}^{0,+}$-mediated glycine transport when present as L-enantiomers. In the case of D-enantiomers, only alanine, serine, methionine, leucine and tryptophan were potent inhibitors. The extent of inhibition was comparable between L-enantiomers and D-enantiomers for these five amino acids. In contrast, the D-enantiomers of threonine, histidine, phenylalanine, and glutamine were much less effective than the corresponding L-enantiomers as inhibitors. Asparagine, lysine, arginine, valine, and isoleucine were almost totally ineffective as inhibitors when present as D-enantiomers even though the corresponding L-enantiomers were potent inhibitors. Since the inhibition does not necessarily mean that the inhibitors are translocated across the membrane via the transporter, a second approach was used in which the transport of L- and D-enantiomeric forms of various amino acids was assessed directly in $X$. laevis oocytes expressing $\mathrm{ATB}^{0,+}$ heterologously. This was done using the two-microelectrode voltageclamp technique and monitoring the amino acid-induced inward currents. The Lenantiomers of all amino acids tested induced inward currents, indicating their transport via $\mathrm{ATB}^{0,+}$. In the case of D-enantiomers, only alanine, serine, methionine, leucine, and tryptophan induced currents. Threonine, histidine, phenylalanine, and glutamine produced small but significant currents whereas the remaining amino acids did not produce currents. These results with the $X$. laevis oocyte expression system corroborate the results with the mammalian cell expression system. These data show that $\mathrm{ATB}^{0,+}$ is capable of transporting all neutral and cationic amino acids when presented as the L-enantiomers. In contrast, the transporter recognizes only alanine, serine, methionine, leucine, and tryptophan in their Denantiomeric form as transportable substrates.

To evaluate the physiological relevance of these findings to the intestinal absorption of ${ }_{D}-$ serine and other D-amino acids via $\mathrm{ATB}^{0,+}$, we assessed the expression pattern of this transporter along the longitudinal axis in the entire intestinal tract in the mouse (Fig. 3). $\mathrm{ATB}^{0,+}$ mRNA is detectable by RT-PCR and semiquantitative RT-PCR only in the cecum, colon, and the terminal part of the small intestine. This expression pattern is unique among the known amino acid transporters. Other transporters $\left(\mathrm{b}^{0,+}, \mathrm{ATB}^{0}\right.$, and L1) are expressed along almost all the intestinal tract. Transcripts for system asc 1 are found in the terminal part of the small intestine, cecum and colon. Immunofluorescent confocal microscopic analysis shows that $\mathrm{ATB}^{0,+}$ is localized to the luminal membrane of the colonic epithelial cells (Fig. 4). 
The observation that the expression of $\mathrm{ATB}^{0,+}$ is restricted only to the distal small intestine and the large intestine suggests that this transporter is uniquely suitable to function in the intestinal absorption of bacteria-derived ${ }_{D}$-serine and other D-amino acids. The sites in the intestinal tract where the expression of $\mathrm{ATB}^{0,+}$ is seen are the same sites where bacterial colonization occurs. Based on these data, we propose a model for the absorption of D-amino acids in the ileum and colon in which $\mathrm{D}$-amino acids are actively absorbed into ileal and colonic epithelial cells via $\mathrm{ATB}^{0,+}$ in a $\mathrm{Na}^{+}$- and $\mathrm{Cl}^{-}$-coupled manner (Fig. 5). $\mathrm{ATB}^{0}$ is also expected to play a role, though to a much lesser extent than $\mathrm{ATB}^{0,+}$, in this process. Thus, D-amino acids enter the intestinal mucosal cells via an energy-coupled process whereas the exit of these amino acids across the basolateral membrane occurs via the facilitative transport systems L1 and asc1.

The human intestine, especially the colon, contains the largest number of bacteria in the body. These microbes and humans coexist with a symbiotic relationship. The bacteria participate actively in modulating the intestinal function (19). The expression of a number of genes that are critical for normal intestinal function is altered significantly by bacterial colonization. The present study suggests that bacteria-derived metabolites may play a role also in shaping human biology. D-serine, produced by the bacteria in the colon and ileum and actively absorbed through the transporter $\mathrm{ATB}^{0,+}$, may exert significant influence on glutamatergic neurotransmission in the brain. $\mathrm{D}$-Serine present in the systemic circulation has access to the brain because the amino acid transport system L1 (LAT1/4F2hc), which has the ability to transport $\mathrm{D}$-serine, is expressed in the blood-brain barrier (20). Furthermore, glutamate signaling via the NMDA receptor occurs in several non-neuronal tissues as diverse as bone, pancreas, and skin (21). D-Serine present in the systemic circulation may have modulatory role in glutamate signaling in these tissues as well.

$\mathrm{ATB}^{0,+}$ is capable of transporting several neutral and cationic amino acids. However, transport of these amino acids may not be the physiological function of $\mathrm{ATB}^{0,+}$ in the intestine. The absorption of protein digestion products occurs almost entirely in the small intestine (22). Protein digestion products rarely enter the colon under physiological conditions. Since $\mathrm{ATB}^{0,+}$ is expressed predominantly in the colon, it is unlikely that the transporter encounters significant amounts of amino acids arising from protein digestion. The physiologic function of $\mathrm{ATB}^{0,+}$ in the colon may be to mediate the absorption of bacteria-derived ${ }_{D}$-serine and other $\mathrm{D}$-amino acids which have the potential of modulating various biological functions in humans. D-Serine is an established neuromodulator and it is interesting that the most likely physiological function of $\mathrm{ATB}^{0,+}$, a member of the neurotransmitter transporter gene family, is to mediate the intestinal transport of this neuromodulator.

\section{ACKNOWLEDGMENTS}

This work was supported by National Institutes of Health Grant GM54122 and Chugai Pharmaceutical Company, Japan.

\section{REFERENCES}

1. Corrigan JJ. Science. 1969; 164:142-149. [PubMed: 5774186] 
2. Friedman M. J. Agric. Food Chem. 1999; 47:3457-3479. [PubMed: 10552672]

3. Man EH, Bada JL. Annu. Rev. Nutr. 1987; 7:209-225. [PubMed: 3300733]

4. Matsui T, Sekiguchi M, Hashimoto A, Tomita U, Nishikawa T, Wada K. J. Neurochem. 1995; 65:454-458. [PubMed: 7790891]

5. Mothet JP, Parent AT, Wolosker H, Brady RO Jr. Linden DJ, Ferris CD, Rogawski MA, Snyder SH. Proc. Natl. Acad. Sci. USA. 2000; 97:4926-4931. [PubMed: 10781100]

6. Wolosker H, Blackshaw S, Snyder SH. Proc. Natl. Acad. Sci. USA. 1999; 96:13409-13414. [PubMed: 10557334]

7. Wolosker H, Sheth KN, Takahashi M, Mothet JP, Brady RO Jr. Ferris CD, Snyder SH. Proc. Natl. Acad. Sci. USA. 1999; 96:721-725. [PubMed: 9892700]

8. Ganapathy, V.; Ganapathy, ME.; Leibach, FH. Current Topics in Membranes. Vol. 50. Academic Press; San Diego: 2001. p. 379-412.

9. Fukasawa Y, Segawa H, Kim JY, Chairoungdua A, Kim DK, Matsuo H, Cha SH, Endou H, Kanai Y. J. Biol. Chem. 2000; 275:9690-9698. [PubMed: 10734121]

10. Kanai Y, Segawa H, Miyamoto K, Uchino H, Takeda E, Endou H. J. Biol. Chem. 1998; 273:23629-23632. [PubMed: 9726963]

11. Palacin M, Estevez R, Bertran J, Zorzano A. Physiol. Rev. 1998; 78:969-1054. [PubMed: 9790568]

12. Hatanaka T, Nakanishi T, Huang W, Leibach FH, Prasad PD, Ganapathy V, Ganapathy ME. J. Clin. Invest. 2001; 107:1035-1043. [PubMed: 11306607]

13. Nakanishi T, Hatanaka T, Huang W, Prasad PD, Leibach FH, Ganapathy ME, Ganapathy V. J. Physiol. (London). 2001; 532:297-304. [PubMed: 11306651]

14. Bridges CC, Kekuda R, Huang W, Prasad PD, Kuhnel JM, Sirotnak FM, Roon P, Ganapathy V, Smith SB. J. Biol. Chem. 2000; 275:20676-20684. [PubMed: 10787414]

15. Ling R, Bridges CC, Sugawara M, Fujita T, Leibach FH, Prasad PD, Ganapathy V. Biochim. Biophys. Acta. 2001; 1512:15-21. [PubMed: 11334620]

16. Sloan JL, Mager S. J. Biol. Chem. 1999; 274:23740-23745. [PubMed: 10446133]

17. Munck LK. Biochim. Biophys. Acta. 1995; 1241:195-213. [PubMed: 7640296]

18. Stevens, BR. Mammalian Amino Acid Transport: Mechanisms and Control. Plenum; New York: 1992. p. 149-164.

19. Hooper LV, Wong MH, Thelin A, Hansson L, Falk PG, Gordon JI. Science. 2001; 291:881-884. [PubMed: 11157169]

20. Boado RJ, Li JY, Nagaya M, Zhang C, Pardridge WM. Proc. Natl. Acad. Sci. USA. 1999; 96:12079-12084. [PubMed: 10518579]

21. Skerry TM, Genever PG. Trends Pharmacol. Sci. 2001; 22:174-181. [PubMed: 11282417]

22. Ganapathy, V.; Leibach, FH. Textbook of Gastroenterology. Lippincott \& Williams; Philadelphia, PA: 1999. p. 456-467. 


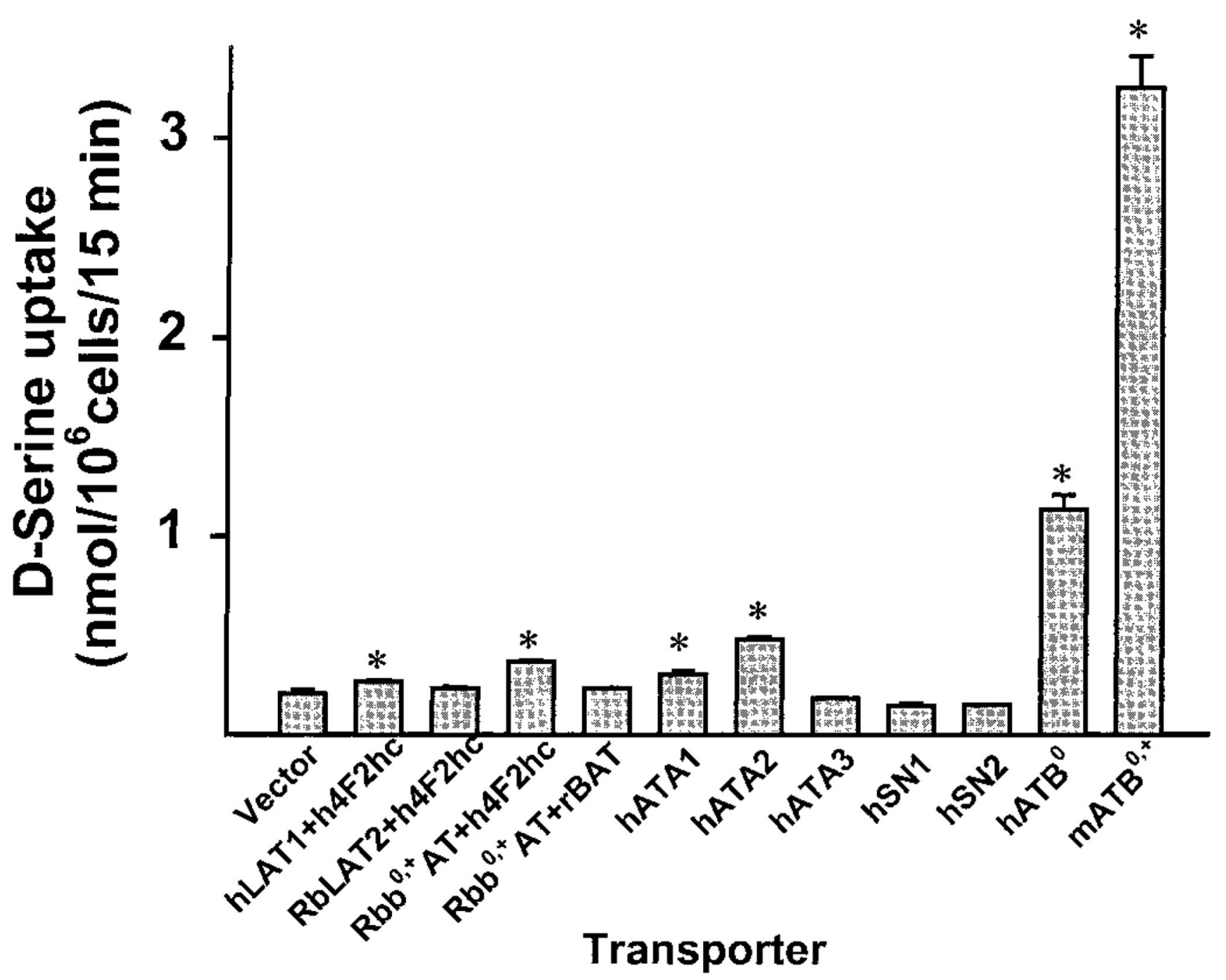

FIG. 1.

Transport of $\mathrm{D}$-serine $(5 \mu \mathrm{M})$ by various amino acid transporters expressed in the intestine. The transporter cDNAs were expressed heterologously in HRPE cells. Where indicated by an asterisk, the transport was significantly $(P<0.05)$ higher than the corresponding transport in vector-transfected cells. 

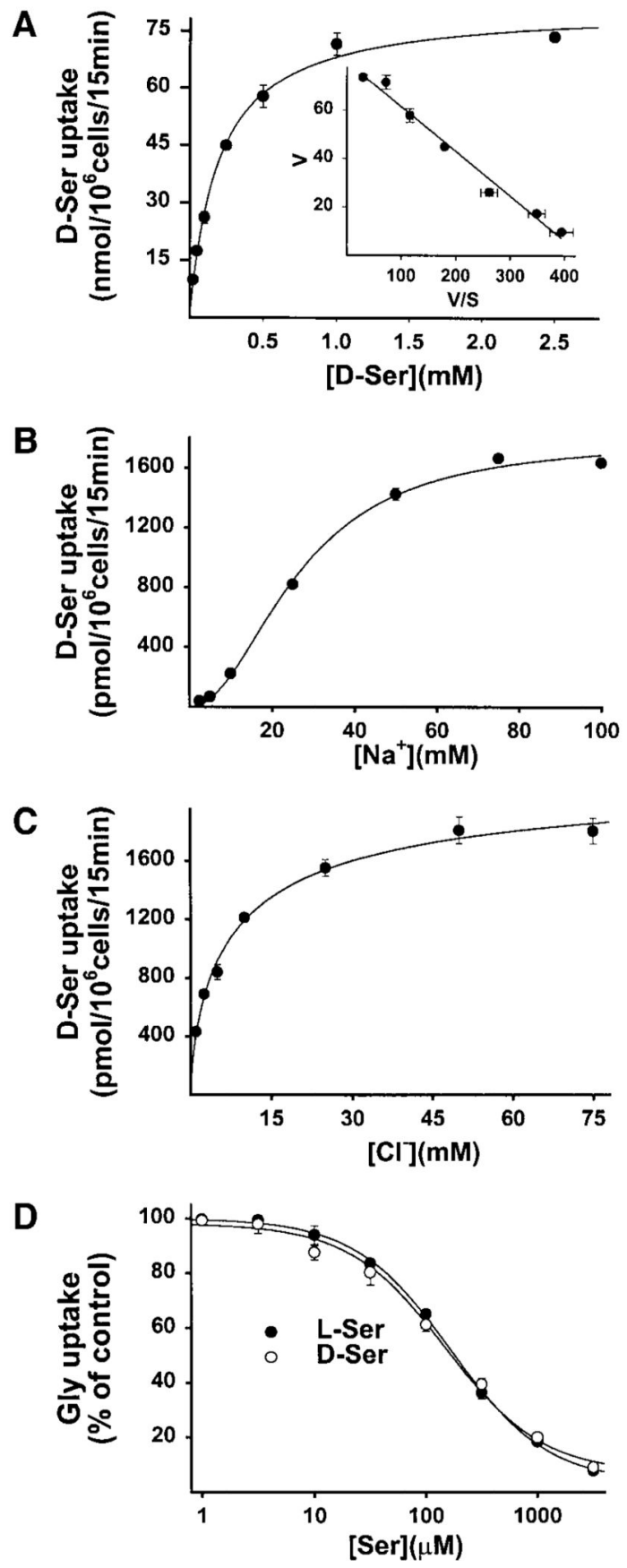

FIG. 2.

Characteristics of $\mathrm{ATB}^{0,+}$-mediated $\mathrm{D}$-serine transport in HRPE cells. The transport of $\mathrm{D}_{\mathrm{D}}$ serine $(\mathrm{A}-\mathrm{C})$ and glycine $(\mathrm{D})$ was measured and the cDNA-specific transport was calculated by subtracting transport in vector-transfected cells from transport in cDNA-transfected cells. 


\section{Small Intestine

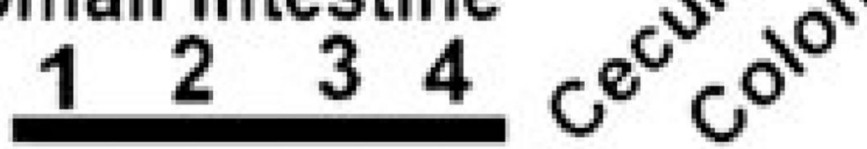

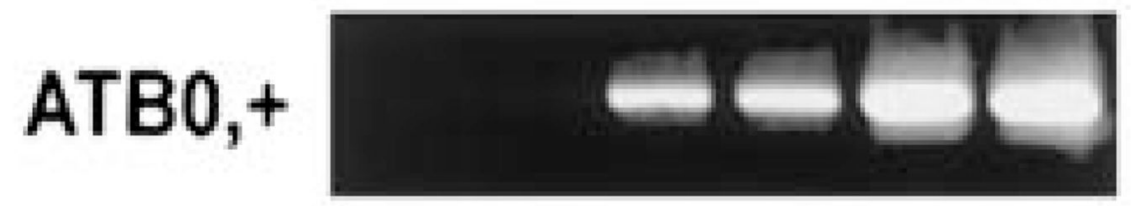

ATB0,+

(SB)

\section{b0,+AT}

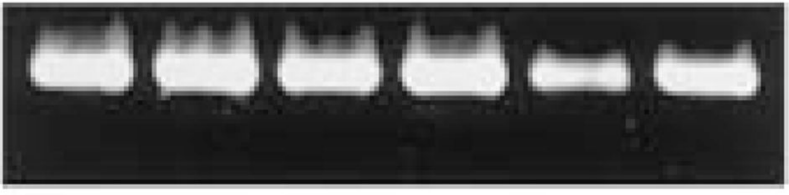

\section{ATB0}

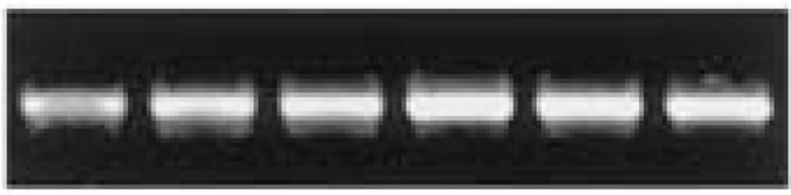

\section{F2hc}
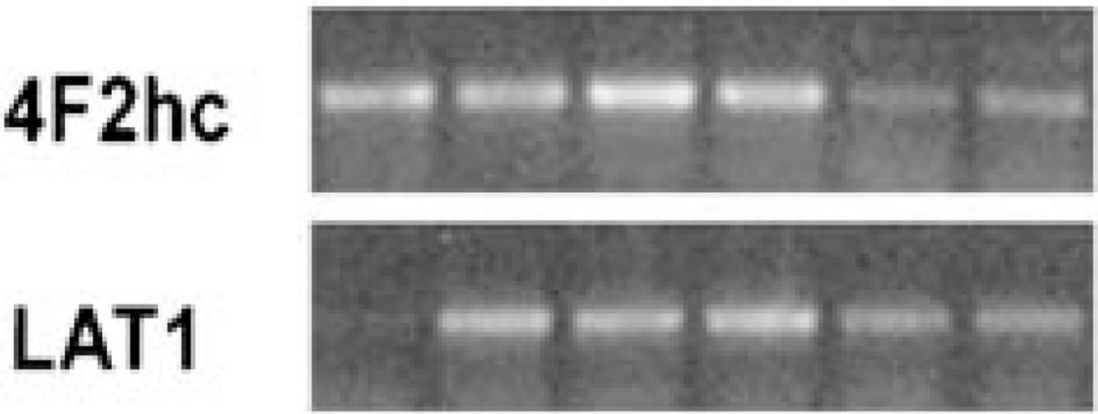

\section{asc1}

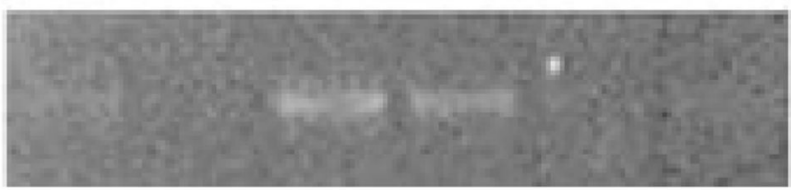

FIG. 3.

Expression pattern of various transporters or transporter components along the longitudinal axis of the mouse intestinal tract. The small intestine was divided into four equal segments, segment 1 representing the most proximal part of the small intestine and segment 4 representing the most distal part of the small intestine. RT-PCR was carried out using mRNA from different regions of the intestinal tract. In the case of $\mathrm{ATB}^{0,+}$, the expression of mRNA was checked also by semiquantitative RT-PCR in which the PCR cycle number was 
low and the RT-PCR product was detected by Southern blot hybridization and quantified (SB). 

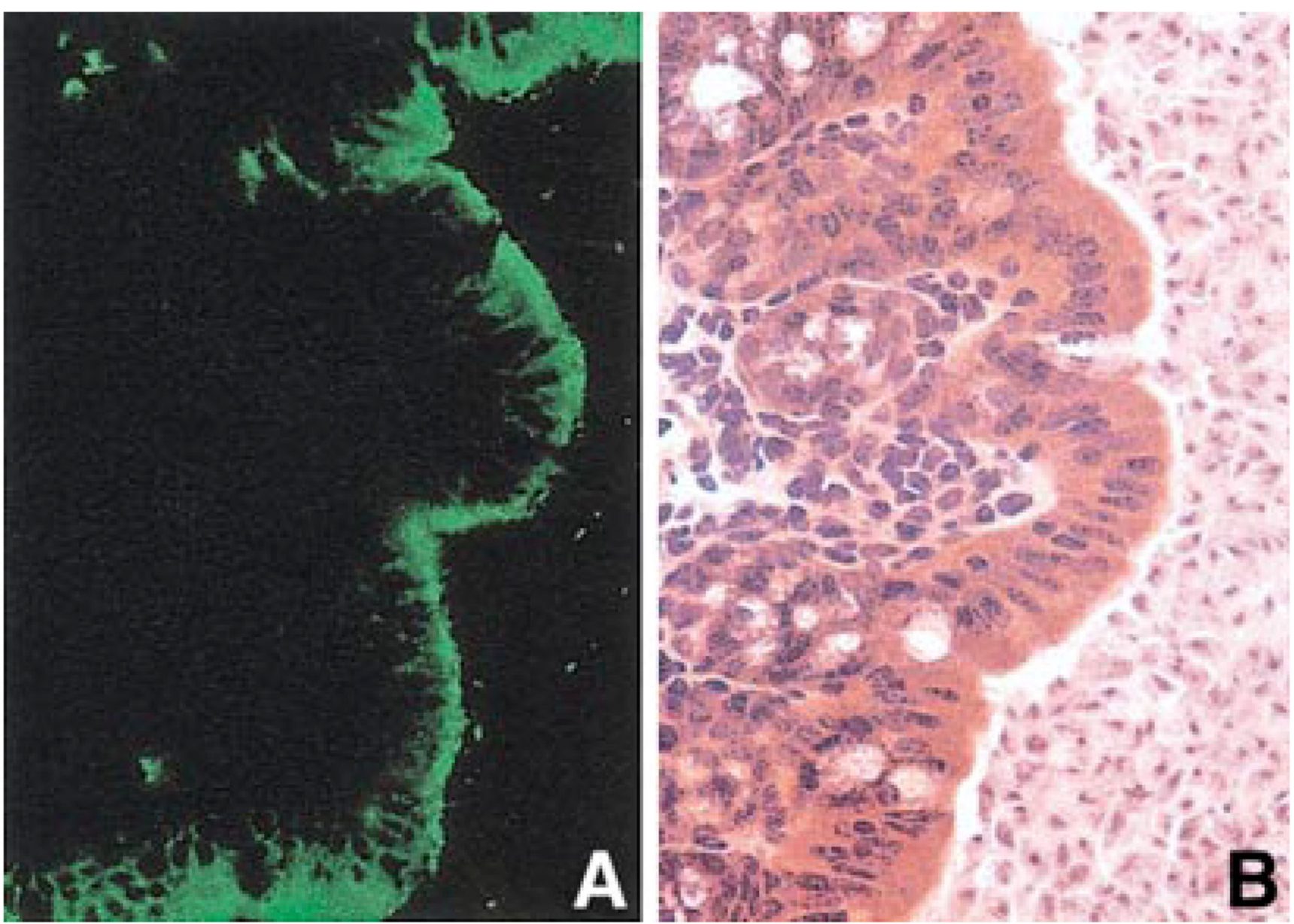

FIG. 4.

Localization of $\mathrm{ATB}^{0,+}$ in mouse colon. (A) Immunofluorescence; (B) hematoxylin-eosin staining. 
Lumen +++ Blood

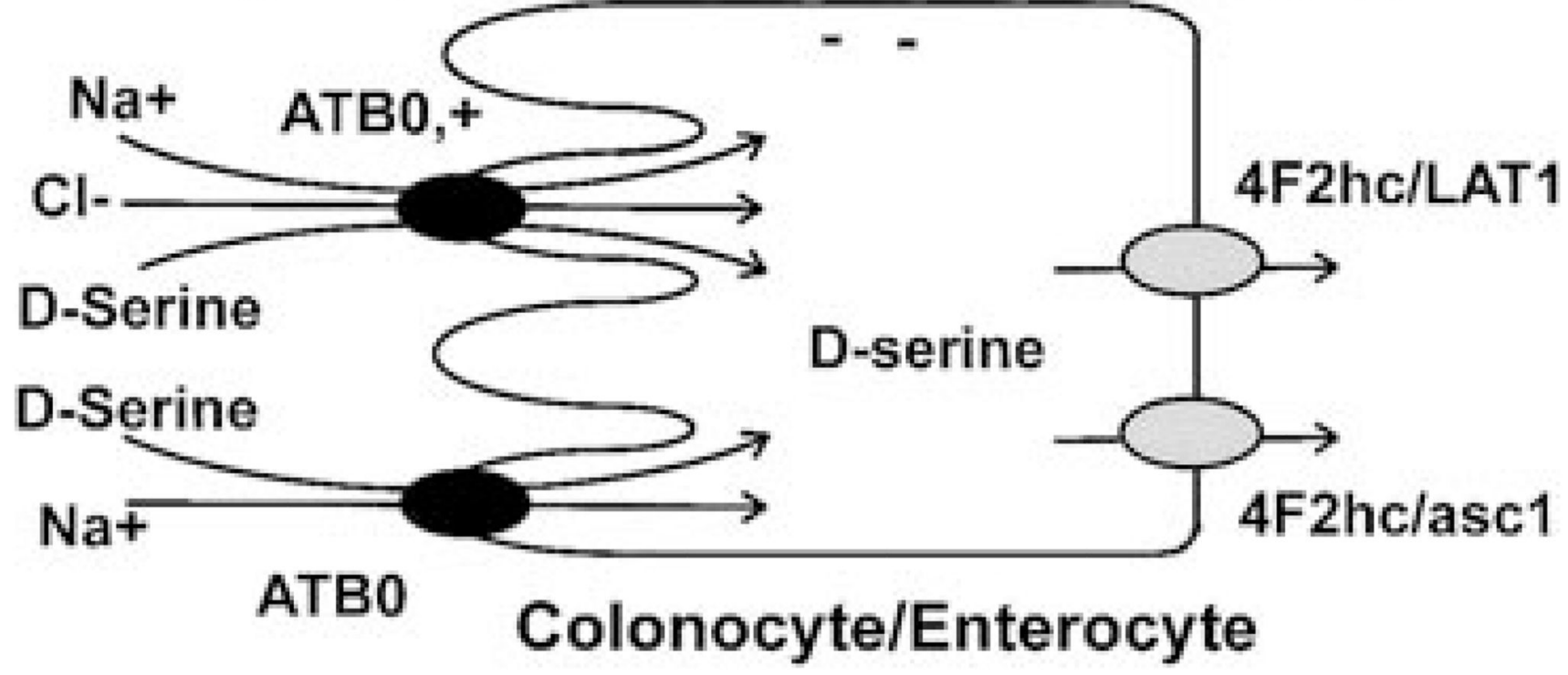

FIG. 5.

A model for the intestinal absorption of ${ }_{D}$-serine from the lumen into the blood. 


\section{TABLE 1}

Relative Transport of L-Amino Acids versus D-Amino Acids via $\mathrm{ATB}^{0,+}$

\begin{tabular}{|c|c|c|c|c|}
\hline \multirow[b]{2}{*}{ Amino acid } & \multicolumn{2}{|c|}{$\begin{array}{c}\text { ATB }^{0,+} \text {-specific } \\
{\left[{ }^{3} \text { H]glycine uptake }\right.} \\
\text { in HRPE cells } \\
(\% \text { control })\end{array}$} & \multicolumn{2}{|c|}{$\begin{array}{c}\text { ATB }^{0,+} \text {-specific } \\
\text { inward current } \\
\text { in } X . \text { laevis } \\
\text { oocytes }(\mathbf{n A})\end{array}$} \\
\hline & L-isomer & D-isomer & L-isomer & D-isomer \\
\hline Control & $100 \pm 6$ & $100 \pm 6$ & & \\
\hline Alanine & $6 \pm 1$ & $10 \pm 1$ & $650 \pm 86$ & $402 \pm 39$ \\
\hline Serine & $10 \pm 1$ & $14 \pm 1$ & $470 \pm 42$ & $267 \pm 23$ \\
\hline Methionine & $3 \pm 0$ & $14 \pm 1$ & $278 \pm 26$ & $213 \pm 15$ \\
\hline Leucine & $3 \pm 1$ & $13 \pm 1$ & $187 \pm 14$ & $161 \pm 25$ \\
\hline Tryptophan & $4 \pm 1$ & $7 \pm 1$ & $112 \pm 4$ & $157 \pm 23$ \\
\hline Threonine & $19 \pm 2$ & $47 \pm 3$ & $233 \pm 12$ & $41 \pm 5$ \\
\hline Histidine & $9 \pm 1$ & $35 \pm 2$ & $410 \pm 64$ & $29 \pm 6$ \\
\hline Phenylalanine & $3 \pm 0$ & $26 \pm 2$ & $275 \pm 58$ & $24 \pm 24$ \\
\hline Glutamine & $13 \pm 1$ & $77 \pm 4$ & $453 \pm 53$ & $16 \pm 11$ \\
\hline Asparagine & $15 \pm 1$ & $95 \pm 7$ & $394 \pm 67$ & $3 \pm 2$ \\
\hline Lysine & $18 \pm 1$ & $86 \pm 5$ & $321 \pm 34$ & $9 \pm 9$ \\
\hline Arginine & $25 \pm 1$ & $93 \pm 6$ & $339 \pm 35$ & $6 \pm 1$ \\
\hline Valine & $7 \pm 1$ & $87 \pm 4$ & $310 \pm 24$ & $4 \pm 3$ \\
\hline Isoleucine & $4 \pm 1$ & $85 \pm 5$ & $117 \pm 16$ & $4 \pm 4$ \\
\hline
\end{tabular}

Note. Human retinal pigment epithelial (HRPE) cells were transfected with either vector alone or mouse $\mathrm{ATB}^{0,+} \mathrm{cDNA}_{\text {and }}$ the functional expression was carried out by the vaccinia virus technique. Transport of $\left[{ }^{3} \mathrm{H}\right]$ glycine $(10 \mu \mathrm{M})$ was measured in the presence and absence of various

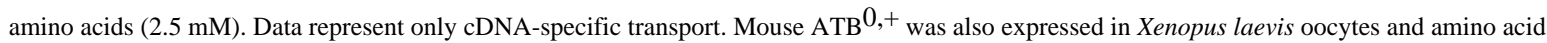
$(1 \mathrm{mM})$-induced currents were monitored using the two-microelectrode voltage-clamp technique. 